Vol. 2, No.1, Januari - Juni 2017

ISSN : 2502-4736

Fakultas Pertanian UNIVERSITAS TRIDINANTI

PALEMBANG

$\frac{3}{3}$

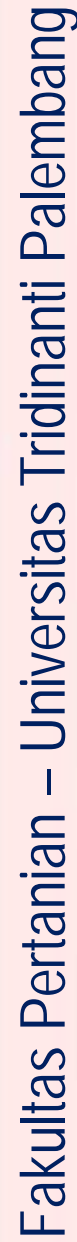

G)
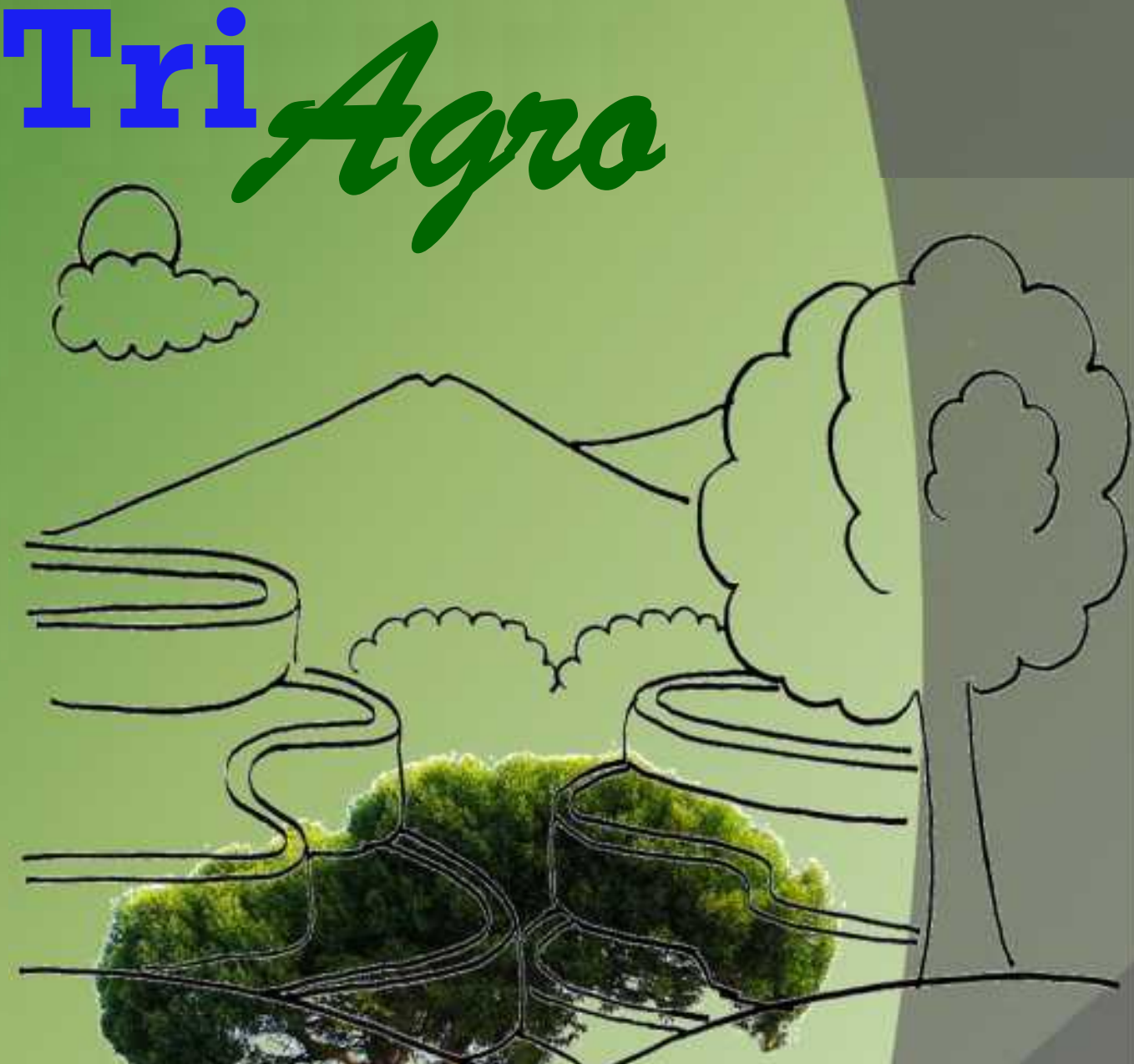

JURNAL Trišrgea

Alamat Redaksi : Fakultas Pertanian Universitas Tridinanti Jalan Kapten Marzuki No, 2446 Kamboja Palembang 30129 Telp. 0711-378387 


\section{Jurnal TRIAGRO}

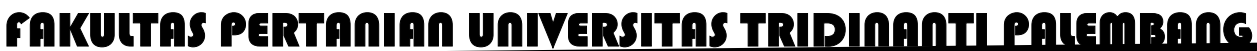

\section{Dewan Redaksi}

Pelindung

Pembina

Pimpinan Umum

Ketua Penyunting

Penyunting Pelaksana

Penyunting Ahli

Dewan Redaksi

Distribusi \& Website
: Dr. Ir. Hj. Manisah MP (Rektor)

: Dr. Nasir Sp. M.Si

: Miranty Trinawaty SP. M.Si

: Prof. Dr. Edizal M.S

- Prof. Dr. Edizal M.S

- Dr.Ir Faridatul Mukminah M.Sc

- Dr. Ir Ruarita RK. MP

: 1. Dr. Ir. Nurmayulis, MP (Universitas Sultan Ageng

Tirtayasa)

2. Dr. Munajat, SP. M.Si (Universitas Baturaja)

:

- Ir. Setiawaty MP

- Ir. Meryanto, M.Si

- Ir. Rostian Nafery, M.Si

- Ir. Ursula Damayanti, MP

- Ir. Ekanovi Aktiva, MM

- Ir. Hj. Yuliantina Azka, MP

: Nova Tri Buyana, Sp 


\section{DAFTAR ISI}

1 RESPON EKSPLAN TANAMAN KENTANG (Solanum tuberrosum L.)

VARIETAS GRANOLA TERHADAP DOSIS PUPUK DAUN DAN KONSENTRASI AIR KELAPA

Rostian Nafery, Zulkarnain Husny, Wendri Pranata *).

2 RESPON PERTUMBUHAN DAN HASIL TANAMAN JAGUNG MANIS

6

(Zea mays saccharata Sturt.) AKIBAT PEMBERIAN BERBAGAI DOSIS

PUPUK ORGANIK CAIR

Ruarita R.K, Ridwan Hanan, Achmad W.A

3 PENGARUH PEMBERIAN ZAT PENGATUR TUMBUH (ZPT)

TERHADAP PERTUMBUHAN DAN HASIL TANAMAN JAGUNG

MANIS (ZEA MAYS SACCHARATA STURT.)

Yuliantina Azka, Meriyanto, Yogi Romadi

PENGARUH PEMBERIAN LIMBAH LUMPUR KERING KELAPA

4 SAWIT TERHADAP PERTUMBUHAN DAN PRODUKSI TANAMAN

TOMAT (Solanum lycopersicum L.)

Bastani Sepindjung, Faridatul Mukminah, Henry Ardiansyah

PENGARUH PEMBERIAN BERBAGAI KONSENTRASI LARUTAN

NUTRISI HIDROPONIK TERHADAP PERTUMBUHAN DAN HASIL

TANAMAN SELADA MERAH (Lactuca sativa L.)DENGAN SISTEM Deep

Flow Technique (DFT)

Meriyanto, Busroni Asnawi, Sari Apriyani

6 PENGARUH PEMBERIAN LARUTAN NUTRISI HIDROPONIK

DENGAN BERBAGAI KONSENTRASI TERHADAP PERTUMBUHAN

DAN HASIL TANAMAN SELADA MERAH (Lactuca sativa L.) DENGAN SISTEM DEEP FLOW TECHNIQUE (DFT)

Meriyanto, Bastani Sepindjung, Rinti Mandasari. 


\section{Pedoman Penulisan Artikel Ilmiah \\ Jurnal TRIAgro \\ Fakultas Pertanian Universitas Tridinanti Palembang}

1. Jurnal ini direncanakan terbit tiga kali dalam setahun, terbuka untuk umum yang ingin mempublikasikan hasil karyanya. Artikel yang ditulis meliputi hasil penelitian di bidang sains.

2. Semua naskah makalah disertai pernyataan bahwa naskah tersebut belum pernah diterbitkan sebelumnya oleh penerbit lain.

3. Setiap naskah yang diterima akan ditinjau/ditelaah oleh ahli dibidangnya sebelum diterbitkan.

4. Naskah tidak dapat diterima jika mengandung unsur politik, komersialisme dan subyektifitas yang berlebihan.

5. Simbol dan terminologi yang digunakan adalah simbol dan terminologi yang lazim digunakan di bidang keahlian masin-masing.

6. Penulis menyetujui untuk mengalihkan hak ciptanya ke redaksi, jika naskahnya diterima untuk diterbitkan.

7. Artikel ditulis dalam bahasa Indonesia atau Inggris. Minimal 10 halaman dan maksimal 15 halaman, termasuk daftar pustaka dan lampiran : ukuran kertas A4, spasi 1,5, margin kiri $4 \mathrm{~cm}$, margin kanan, atas dan bawah masing-masing $3 \mathrm{~cm}$, menggunakan Times New Roman Font 11.

8. Artikel diketik dengan program MS Word, penulis dimohon mengirimkan satu print out dan satu CD yang berisi artikel, cantumkan alamat email dan no telepon/hp penulis untuk keperluan konfirmasi tentang tulisan yang dikirimkan ke redaksi.

9. Artikel dilengkapi :

Abstrak tidak lebih dari 200 kata dengan kata-kata kunci, biodata singkat penulis dan identitas penelitian dicantumkan sebagai cat kaki pada halaman pertma artikel.

10. Penulisan daftar pustaka mengikuti penulisan yang baik dan benar 


\section{KATA PENGANTAR}

Terima kasih atas berkah Tuhan Yang Maha Kuasa dan Rahmat-Nya, maka Jurnal TriAgro Fakultas Pertanian Universitas Tridinanti Palembang ini dapat diterbitkan. Jurnal ini diharapkan dapat menampung informasi dunia pertanian modern dan menyebarkan informasi di lingkup pertanian baik secara umum maupun khusus, penerbitan jurnal ini diharapkan dapat menjadi sarana untuk menampung tulisan-tulisan ilmiah pertanian.

Dewan redaksi mengucapkan terima kasih kepada semua pihak yang telah memerikan bantuan teknis maupun non teknis untuk terbitnya jurnal TriAgro ini. Dewan redaksi sangat mengharapkan partisipasi peneliti untuk menyumbangkan tulisannya ke jurnal TriArgro ini guna menjaga kelancaran penerbitan, yaitu dua kali setahun.

Dewan redaksi mengucapkan terima kasih kepada Bapak/Ibu/Saudara yang telah berpartisipasi pada jurnal edisi ini. Semoga Jurnal ini dapat memberikan manfaat kepada Bapak/Ibu/Saudara semuanya. 


\title{
RESPON PERTUMBUHAN DAN HASIL TANAMAN JAGUNG MANIS (Zea mays saccharata Sturt.) AKIBAT PEMBERIAN BERBAGAI DOSIS PUPUK ORGANIK CAIR
}

\author{
RUARITA R.K ${ }^{1}$, RIDWAN HANAN ${ }^{2}$, ACHMAD W.A ${ }^{3}$ \\ ${ }^{12}$ Dosen Program Studi Agroteknologi, ${ }^{3}$ Mahasiswa Program Studi Agroteknologi \\ Program Studi Agroteknologi, Fakultas Pertanian, Universitas Tridinanti Palembang \\ J1. Kapten Marzuki No.2445, Kamboja, Palembang30129
}

\section{RINGKASAN}

Penelitian ini bertujuan untuk mengetahui pengaruh pemberian berbagai dosis pupuk organik cair terhadap pertumbuhan dan produksi tanaman jagung manis (Zea mays saccharata Strurt.) Penelitian ini dilaksanakan di Sukawinatan, Kelurahan Kemuning, Palembang pada bulan Desember 2012 sampai dengan bulan Maret 2013. Rancangan penelitian yang digunakan adalah metode percobaan dengan Rancangan Acak Kelompok (RAK) non faktorial, dengan 4

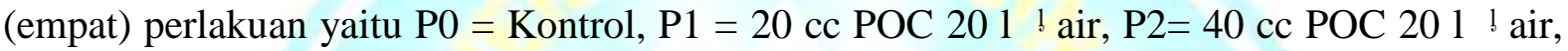
P3 = 60 cc POC 201 ' air. Perlakuan tersebut diulang sebanyak 6 (enam) kali sehingga terdapat 24 satuan percobaan. Peubah yang diamati yaitu : Tinggi Tanaman $(\mathrm{cm})$, Jumlah Daun (helai), Umur Berbunga (hari), Panjang Tongkol $(\mathrm{cm})$, Diameter Tongkol $(\mathrm{cm})$, Bobot Tongkol Segar per Tanaman (g), Hasil per Petak Panen (kg). Bedasarkan hasil penelitian menunjukkan bahwa, pemberian dosis pupuk organik cair dengan dosis P3 (60 cc POC 201 l air) dapat menghasilkan tinggi tanaman rata-rata sebesar $135.08 \mathrm{~cm}$, jumlah daun rata-rata sebanyak 10.13 helai, umur berbunga rata-rata 45.5 hari, diameter tongkol rata-rata $4.30 \mathrm{~cm}$, panjang tongkol rata-rata $15.35 \mathrm{~cm}$, berat per tanaman rata-rata $214.17 \mathrm{~g}$ dan hasil per petak panen rata-rata $3.38 \mathrm{~kg}$.

Kata Kunci : Jagung Manis, Pupuk Organik Cair (POC)

\section{PENDAHULUAN}

Jagung telah dibudidayakan di Amerika Tengah (Meksiko bagian Selatan) sekitar 8.000 sampai 10.000 tahun yang lalu. Dari penggalian ditemukan fosil tongkol jagung dengan ukuran kecil, yang diperkirakan usianya mencapai sekitar 7.000 tahun. Menurut pendapat beberapa ahli botani, teosinte (Zea mays sp. Parviglumis) sebagai nenek moyang tanaman jagung, merupakan tumbuhan liar yang berasal dari lembah Sungai Balsas, lembah di Meksiko Selatan. Bukti genetik, antropologi, dan arkeologi menunjukkan bahwa daerah asal jagung adalah Amerika Tengah dan dari daerah ini jagung tersebar dan ditanam di seluruh dunia (Iriany, 2007). Di Indonesia, daerah-daerah penghasil utama tanaman jagung adalah Jawa Barat, Jawa Tengah, Jawa Timur, Madura, Daerah Istimewa Yogyakarta, Nusa Tenggara Timur, Sulawesi Utara, Sulawesi Selatan, dan Maluku. Khusus di daerah Jawa Timur dan Madura, budidaya tanaman jagung 
dilakukan secara intensif karena kondisi tanah dan iklimnya sangat mendukung untuk pertumbuhannya (Tim Karya Tani Mandiri, 2010).

Menurut data Badan Pusat Statistik (2009), produksi jagung di Provinsi Sumatera Selatan sebanyak 166,129 ton per tahun. Hasil produksi jagung terkonsentrasi di Kabupaten Ogan Komering Ilir (OKI) dengan produksi sebanyak 119.850 ton per tahun, Kabupaten Musi Banyuasin (MUBA) sebanyak 30,960 ton per tahun, dan di Kabupaten Banyuasin sebanyak 15,319 ton per tahun.

Tanaman jagung secara spesifik merupakan tanaman pangan yang sangat bermanfaat bagi kehidupan manusia ataupun hewan. Jagung merupakan makanan pokok kedua setelah padi di Indonesia. Sedangkan, berdasarkan urutan bahan makanan pokok di dunia, jagung menduduki urutan ketiga setelah gandum dan padi. Tanaman jagung hingga kini dimanfaatkan oleh masyarakat dalam berbagai bentuk penyajian, seperti: tepung jagung (maizena), minyak jagung, bahan pangan, serta sebagai pakan ternak dan lain-lainnya. Khusus jagung manis (sweet corn) sangat disukai dalam bentuk jagung rebus dan bakar (Derna, 2007). Menurut Sudarsana (2000), bahwa jagung manis merupakan komoditas pertanian yang sangat digemari terutama oleh penduduk perkotaan, karena rasanya yang enak dan manis banyak mengandung karbohidrat, sedikit protein dan lemak. Budidaya jagung manis berpeluang memberikan untung yang tinggi bila diusahakan secara efektif dan efisien.

Dikemukakan oleh Harizamry (2007), bahwa jagung manis mengandung kadar gula yang relatif tinggi, karena itu biasanya dipanen muda untuk dibakar atau direbus. Ciri dari jenis ini adalah bila masak bijinya menjadi keriput dan bermanfaat sebagai bahan makanan, makanan ternak, bahan baku pengisi obat dan lain-lain. Tanaman jagung tidak akan memberikan hasil maksimal apabila unsur hara yang diperlukan tidak cukup tersedia. Pemupukan dapat meningkatkan hasil panen secara kuantitatif maupun kualitatif.

Lingga dan Marsono (2001) menyatakan bahwa, pupuk merupakan kunci dari kesuburan tanah karena berisi satu atau lebih unsur untuk menggantikan unsur yang diserap tanaman. Nihayati dan Damhuri (2004) mengemukakan bahwa, pertumbuhan tanaman yang baik diperlukan pemberian pupuk yang memadai. Pemupukan merupakan faktor yang sangat berpengaruh terhadap hasil jagung manis. Berbagai upaya dapat dilakukan untuk menghasilkan produksi jagung manis. Salah satu upaya untuk meningkatkan produksi jagung manis dapat ditempuh dengan pemberian pupuk dan pengaturan jarak tanam. Pupuk terbagi menjadi dua macam yaitu pupuk organik dan pupuk anorganik (Rahmi dan Jumiati, 2007).

Pupuk organik adalah pupuk yang sebagian besar atau seluruhnya terdiri atas bahan organik yang berasal dari tanaman atau hewan yang telah melalui proses dari rekayasa, dapat berbentuk padat atau cair yang digunakan untuk mensuplai bahan organik untuk memperbaiki sifat fisik, biologi dan kimia tanah (Suriadikarta dan Simanungkalit, 2006). Pemupukan melalui tanah kadang-kadang kurang bermanfaat, karena berbagai unsur hara telah larut lebih dahulu dan hilang melalui air perkolasi atau mengalami fiksasi oleh koloid tanah sehingga tidak dapat diserap oleh tanaman. Upaya yang dapat ditempuh agar pemupukan lebih efektif dan efesien adalah dengan cara menyemprotkan larutan pupuk melalui daun tanaman.

Pupuk organik cair (POC), adalah jenis pupuk yang berbentuk cair tidak padat yang mudah sekali larut pada tanah dan membawa unsur-unsur penting guna kesuburan tanah. Pupuk organik cair adalah pupuk yang dapat memberikan hara 
yang sesuai dengan kebutuhan tanaman pada tanah, karena bentuknya yang cair, maka jika terjadi kelebihan kapasitas pupuk pada tanah dengan sendirinya tanaman akan mudah mengatur penyerapan komposisi pupuk yang dibutuhkan (Yulianti, 2000). Pemberian pupuk organik cair harus memperhatikan konsentrasi atau dosis yang diaplikasikan terhadap tanaman. Penelitian menunjukkan bahwa pemberian pupuk organik cair melalui daun memberikan pertumbuhan dan hasil tanaman yang baik dibandingkan dengan pemberian melalui tanah (Hanolo, 1997). Semakin tinggi dosis pupuk yang diberikan maka kandungan unsur hara yang diterima oleh tanaman akan semakin tinggi, begitu juga dengan semakin seringnya frekuensi aplikasi pupuk daun yang dilakukan pada tanaman, maka kandungan unsur hara juga semakin tinggi. Namun, pemberian dengan dosis yang berlebihan justru akan mengakibatkan timbulnya gejala kelayuan pada tanaman (Suwandi dan Nurtika 1987). Oleh karena itu, pemilihan dosis yang tepat perlu diketahui oleh para peneliti dan hal ini dapat diperoleh melalui pengujian-pengujian di lapangan (Rizqiani, dkk., 2007).

Menurut Rahmi dan Jumiati (2007), bahwa perlakuan waktu penyemprotan pupuk organik cair (POC) Super ACI pada tanaman jagung manis 15 hari, 30 hari, dan 45 hari setelah tanam ternyata dapat menghasilkan tanaman yang lebih tinggi, umur tanaman saat keluar bunga betina dan umur panen yang lebih cepat, komponen tongkol yang besar dan lebih berat serta produksi tongkol yang lebih tinggi dibandingkan dengan perlakuan waktu penyemprotan pupuk organik cair Super ACI 12 hari, 24 hari, dan 42 hari dan perlakuan waktu penyemprotan pupuk organik cair Super ACI 18 hari, 36 hari, dan 54 hari. Pemberian upuk organik cair dengan dosis $4 \mathrm{ml} \mathrm{l}^{-1}$ dengan waktu penyemprotan 2 (dua) hari, 4 (empat) hari, dan 6 (enam) hari setelah tanam menghasilkan hasil yang signifikan terhadap jumlah daun, diameter umbi dan berat basah tanaman kentang (Parman, 2007). Penggunaan pupuk organik cair (POC) yang dianjurkan untuk tanaman pangan dan sayur mayur yaitu sebanyak 20 cc sampai $60 \mathrm{cc}$ per 10 liter sampai 30 liter air.

\section{TUJUAN PENELITIAN}

Tujuan dari penelitian ini adalah untuk mengetahui respon pertumbuhan dan hasil tanaman jagung manis (Zea mays saccharata Sturt) akibat pemberian berbagai dosis pupuk organik cair.

\section{BAHAN DAN METODE}

Penelitian ini telah dilaksanakan pada bulan Desember 2012 sampai bulan Maret 2013 di Sukawinatan, Kelurahan Kemuning, Palembang dengan ketinggian $24 \mathrm{~m}$ di atas permukaan laut (dpl). Bahan yang digunakan dalam penelitian ini antara lain : benih jagung manis Varietas Super Bee, pupuk organik cair (POC), pupuk N, $\mathrm{P}$, dan K (sebagai pupuk dasar), Fungisida, Insektisida, air, serta bahan-bahan lain yang diperlukan dalam penelitian. Alat yang digunakan dalam penelitian ini adalah cangkul, parang, babat, gembor, tali rafia, tangki, meteran, gunting, papan sampel, timbangan, kalkulator, alat tulis dan peralatan lain yang diperlukan dalam penelitian.

Penelitian ini dilakukan dengan menggunakan metode percobaan (eksperiment) Rancangan Acak Kelompok (RAK) yang terdiri dari 4 (empat) perlakuan dan diulang sebanyak 6 (enam) kali, sehingga didapat 24 satuan percobaan. Jumlah sampel yang diamati dalam setiap satuan percobaan diambil sebanyak 4 (empat) tanaman dengan ukuran petakan untuk setiap satuan percobaan berukuran 2 meter $\mathrm{x} 3$ meter 
dengan jarak tanam $50 \mathrm{~cm}$ x $30 \mathrm{~cm}$. Perlakuan untuk percobaan ini adalah dosis pemberian pupuk organik cair (POC) yang terdiri dari 4 (empat) level, yaitu : P0 $=$ kontrol (hanya disemprot air saja), P1 $=20 \mathrm{cc}$ POC $201 \mathrm{l}^{\mathrm{air}, \mathrm{P} 2}=40 \mathrm{cc}$ POC 201' air dan P3 = 60 cc POC 201 l air. Respon tanaman jagung manis pada percobaan ini akan dilakukan

\section{HASIL DAN PEMBAHASAN}

pengamatan peubah pada tanaman yaitu : Tinggi Tanaman (cm), Jumlah Daun (helai), Umur Berbunga (hst), Panjang dan Diameter Tongkol $(\mathrm{cm})$, Bobot Tongkol segar per Tanaman (g) dan Hasil per petak Panen (kg).

Hasil analisis keragaman terhadap semua peubah yang diamati dapat dilihat pada Tabel 3 berikut ini :

Tabel 1. Analisis Keragaman Semua Peubah yang Diamati

\begin{tabular}{lrr}
\hline \multicolumn{1}{c}{ Peubah yang Diamati } & Uji F & KK (\%) \\
\hline Tinggi Tanaman 2 Minggu Setelah Tanam $(\mathrm{cm})$ & $2.21^{\mathrm{tn}}$ & 7.30 \\
Tinggi Tanaman 3 Minggu Setelah Tanam $(\mathrm{cm})$ & $1.37^{\text {tn }}$ & 7.32 \\
Tinggi Tanaman 4 Minggu Setelah Tanam $(\mathrm{cm})$ & $4.32^{\mathrm{n}}$ & 5.14 \\
Tinggi Tanaman 5 Minggu Setelah Tanam $(\mathrm{cm})$ & $5.54^{\mathrm{sn}}$ & 5.46 \\
Tinggi Tanaman 6 Minggu Setelah Tanam $(\mathrm{cm})$ & $12.24^{\mathrm{sn}}$ & 2.80 \\
Jumlah Daun 2 Minggu Setelah Tanam (helai) & $0.16^{\mathrm{tn}}$ & 14.14 \\
Jumlah Daun 3 Minggu Setelah Tanam (helai) & $2.82^{\text {tn }}$ & 8.63 \\
Jumlah Daun 4 Minggu Setelah Tanam (helai) & $3.39^{\mathrm{n}}$ & 9.73 \\
Jumlah Daun 5 Minggu Setelah Tanam (helai) & $4.05^{\mathrm{n}}$ & 5.85 \\
Jumlah Daun 6 Minggu Setelah Tanam (helai) & $4.77^{\mathrm{n}}$ & 4.25 \\
Umur Berbunga (hari) & $15.40^{\mathrm{sn}}$ & 1.14 \\
Diameter Tongkol (cm) & $10.46^{\mathrm{sn}}$ & 6.93 \\
Panjang Tongkol (cm) & $4.29^{\mathrm{n}}$ & 3.36 \\
Bobot Tongkol per Tanaman (g) & $15.40^{\mathrm{sn}}$ & 7.29 \\
Hasil per Petak Panen $(\mathrm{kg})$ & $25.98^{\mathrm{sn}}$ & 3.52 \\
\hline
\end{tabular}

Keterangan: $\quad{ }^{\mathrm{tn}}=$ berbeda tidak nyata

${ }^{n}=$ berbeda nyata

${ }^{\mathrm{sn}}=$ berbeda sangat nyata

Hasil pengamatan tinggi tanaman pada 2, 3, 4, 5 dan 6 minggu setelah tanam dapat dilihat pada lampiran 7, 8, 9, 10 dan 11. Hasil Analisis keragaman pada Tabel 1 menunjukkan bahwa pemberian pupuk organik cair berpengaruh tidak nyata terhadap tinggi tanaman pada minggu ke 2

dan 3 setelah tanam, dan berpengaruh nyata sampai sangat nyata pada minggu ke 4, 5 dan 6 setelah tanam. Beda antar perlakuan berdasarkan Uji BNJ dapat dilihat pada Tabel 2 berikut ini :

Tabel 2. Pengaruh Pemberian Pupuk Organik Cair terhadap Tinggi Tanaman

\begin{tabular}{|c|c|c|c|c|}
\hline \multirow{2}{*}{ Perlakuan } & \multicolumn{4}{|c|}{ Tinggi Tanaman $(\mathrm{cm})$} \\
\hline & $4 \mathrm{MST}$ & $5 \mathrm{MST}$ & $6 \mathrm{MST}$ & \\
\hline $\mathrm{P} 0$ & $77.70 \quad \mathrm{a}$ & $97.82 \quad \mathrm{a}$ & 125.42 & A \\
\hline P1 & $81.02 \mathrm{ab}$ & 98.35 a & 123.45 & A \\
\hline P2 & $83.25 \mathrm{ab}$ & $106.00 \mathrm{ab}$ & 129.47 & $\mathrm{Ab}$ \\
\hline
\end{tabular}




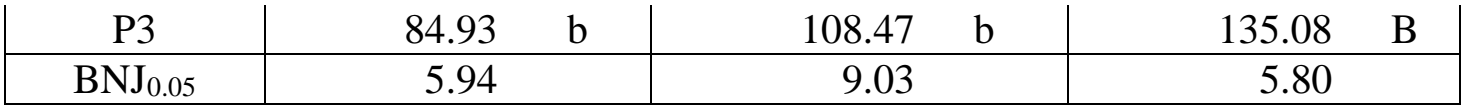

Keterangan : Angka yang diikuti oleh huruf yang sama pada kolom yang sama tidak berbeda nyata pada taraf uji $0,05 \%(\mathrm{BNJ})$

Data pengamatan jumlah daun pada 2, 3, 4, 5 dan 6 minggu setelah tanam dapat dilihat pada lampiran 11, 12, 13, 14 dan 15. Hasil analisis keragaman pada Tabel 1 menunjukkan bahwa pemberian pupuk organik cair berpengaruh tidak nyata terhadap jumlah daun tanaman pada minggu ke 2 dan 3 setelah tanam, berpengaruh nyata sampai sangat nyata pada minggu ke 4, 5 dan 6 setelah tanam. Beda antar perlakuan berdasarkan Uji BNJ dapat dilihat pada Tabel 3 .

Tabel 3. Pengaruh Pemberian Pupuk Organik Cair terhadap Jumlah Daun

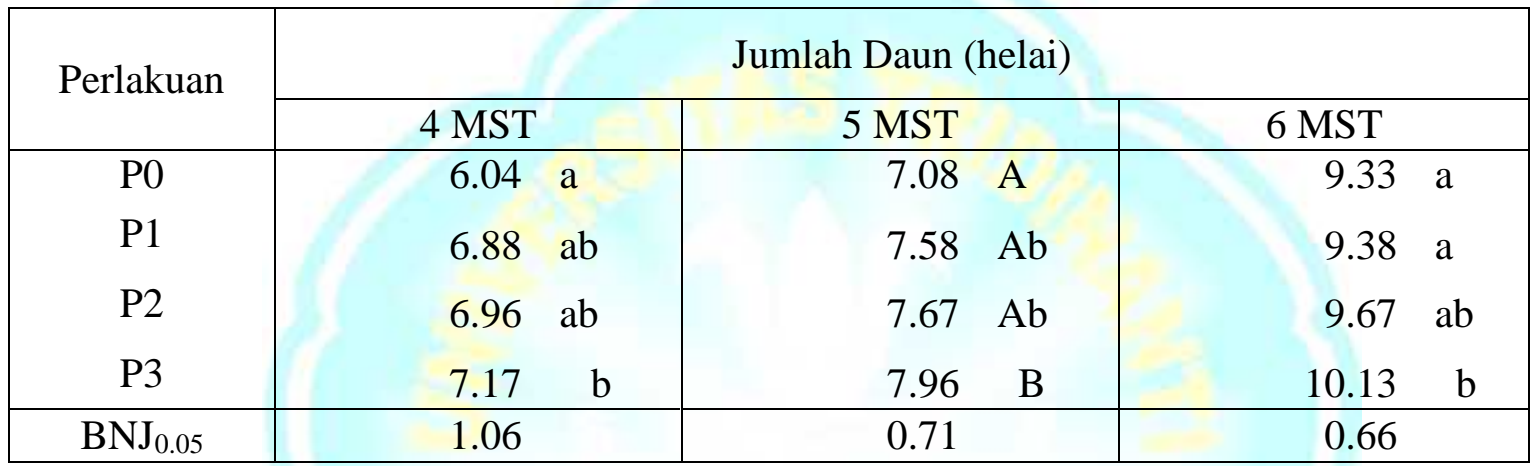

Keterangan : Angka yang diikuti oleh huruf yang sama pada kolom yang sama tidak berbeda nyata pada taraf uji $0,05 \%(\mathrm{BNJ})$

Tabel 4. Pengaruh Pemberian Pupuk Organik Cair terhadap Umur Berbunga, Diameter Tongkol dan Panjang Tongkol

\begin{tabular}{|c|c|c|c|}
\hline Perlakuan & Umur Berbunga (hari) & Diameter Tongkol $(\mathrm{cm})$ & Panjang Tongkol (cm) \\
\hline P0 & $47.33 \quad \mathrm{a}$ & $3.46 \quad \mathrm{a}$ & $14.33 \mathrm{a}$ \\
\hline P1 & $46.50 \mathrm{ab}$ & $3.90 \mathrm{ab}$ & $14.92 \mathrm{ab}$ \\
\hline P2 & $45.67 \quad b c$ & 4.10 & $15.02 \mathrm{ab}$ \\
\hline P3 & 45.50 & 4.30 & 15.35 \\
\hline $\mathrm{BNJ}_{0.05}$ & 0.85 & 0.44 & 0.81 \\
\hline
\end{tabular}

Keterangan : Angka yang diikuti oleh huruf yang sama pada kolom yang sama tidak berbeda nyata pada taraf uji $0,05 \%(\mathrm{BNJ})$

Hasil analisis ragam pada Tabel 1 menunjukkan bahwa pemberian pupuk organik cair berpengaruh sangat nyata terhadap berat tongkol per tongkol yang dihasilkan. Beda antar perlakuan berdasarkan Uji BNJ dapat dilihat pada
Tabel 5. Pada Tabel 5 terlihat bahwa perlakuan P3 menghasilkan berat tongkol per tongkol yang lebih berat dan berbeda nyata terhadap $\mathrm{P} 0$ dan $\mathrm{P} 1$, sedangkan terhadap P2 menunjukkan berat tongkol per tongkol yang berbeda tidak nyata.

Tabel 5. Pengaruh Pemberian Pupuk Organik Cair terhadap Berat Tongkol per Tongkol dan Hasil per Petak Panen 


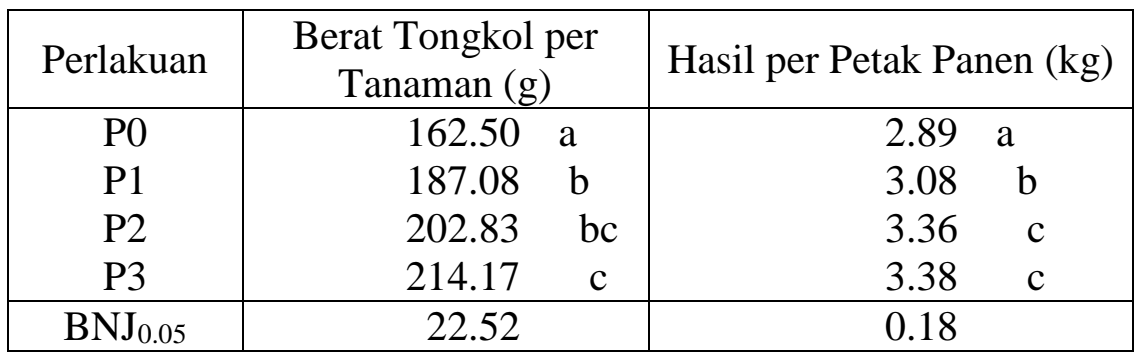

Keterangan : Angka yang diikuti oleh huruf yang sama pada kolom yang sama tidak berbeda nyata pada taraf uji $0,05 \%(\mathrm{BNJ})$

Hasil analisis keragaman pada tabel 1 menunjukkan, bahwa pemberian pupuk organik cair berpengaruh tidak nyata terhadap tinggi tanaman dan jumlah daun pada minggu ke 2 dan 3 setelah tanam, dan berpengaruh nyata sampai sangat nyata pada minggu ke 4 , 5 dan 6 setelah tanam. Pemberian pupuk organik cair masih belum berpengaruh terhadap tanaman pada minggu ke 2 dan 3 setelah tanam, diduga karena tanaman masih muda dan jumlah daun masih sedikit sehingga penyerapan pupuk cair belum terserap dengan baik oleh tanaman. Pada minggu ke 4 dan seterusnya, tanaman telah memiliki perakaran yang banyak dan daun yang cukup sehingga pemberian pupuk organik cair lewat daun diduga dapat diserap dan menambah ketersediaan hara bagi tanaman untuk proses pertumbuhannya. Menurut Rahmi dan Jumiati (2007), pupuk organik cair selain mengandung hara makro juga mengandung hara mikro yang sangat penting bagi tanaman. Pupuk tersebut mudah larut dan lebih cepat diserap oleh tanaman sehingga dapat memacu pertumbuhan dan perkembangan tanaman. Sejalan dengan penelitian Azhari (2009) yang menyatakan bahwa pemberian pupuk oranik cair berpengaruh baik pada tinggi tanaman.

Pemberian pupuk daun berpengaruh nyata sampai sangat nyata terhadap umur berbunga, diameter tongkol, panjang tongkol, berat tongkol per tanaman dan hasil per petak panen. Diduga pupuk organik cair yang diberikan dapat diserap tanaman sehingga kebutuhan tanaman akan hara makro dan mikro dapat terpenuhi. Sejalan dengan hasil penelitian Rahmi dan Jumiati (2007) bahwa pemberian pupuk organik cair berpengaruh baik pada umur berbunga, diameter tongkol, panjang tongkol, bobot tongkol dan produksi tongkol.

Perlakuan P3 (60 cc POC 2011 air) menghasilkan tinggi tanaman, jumlah daun, umur berbunga, diameter panjang tongkol dan berat tongkol yang lebih baik dari perlakuan lain, diduga pupuk organik cair yang diberikan pada konsentrasi P3 tersebut sesuai dengan kebutuhan tanaman sehingga tanaman dapat tumbuh lebih cepat dan lebih baik. Lingga (2003) menjelaskan bahwa pemberian pupuk daun dapat memberikan hasil yang baik jika konsentrasi yang diberikan sesuai dengan kebutuhan tanaman, dan diduga pupuk organik cair dengan dosis P3 (60 cc POC 201 a air) sesuai dengan kebutuhan tanaman, ketersedian hara yang cukup akan memacu pertumbuhan generatif tanaman, sehingga dapat mempercepat proses pertumbuhan tanaman, mempercepat proses pembungaan dan menghasilkan tongkol yang lebih besar. Unsur hara yang berperan dalam pertumbuhan generatif tanaman adalah unsur hara $\mathrm{N}$ dan $\mathrm{P}$, dan pada perlakuan pada dosis P3 (60 cc POC 201 l air) memberikan unsur hara $\mathrm{N}, \mathrm{P}$ dan $\mathrm{K}$ yang lebih tinggi dibanding perlakuaan yang 
lain. Darmanti (2006) mengungkapkan bahwa, unsur hara $\mathrm{N}$ ikut berperan dalam proses pembungaan, sedangkan unsur hara $\mathrm{P}$ berperan dalam proses pembentukan bunga selanjutnya mempengruhi pembentukan tongkol dan ukuran tongkol. Hal ini didukung oleh pernyataan Sutedjo (1955) dalam Darmanti (2006), untuk mendorong proses pembentukan bunga dan buah sangat diperlukan unsur $P$.

\section{KESIMPULAN}

Berdasarkan hasil penelitian yang dilakukan dapat disimpulkan bahwa, pemberian pupuk organik cair pada konsentrasi 60 cc POC 201 l air (P3) berpengaruh baik terhadap pertumbuhan dan hasil tanaman jagung manis. Pemberian dosis pupuk organik cair $60 \mathrm{cc}$ POC $20 \quad 1 \quad l$ air menghasilkan tinggi tanaman rata-rata sebesar $135.08 \mathrm{~cm}$, jumlah daun rata-rata sebanyak 10.13 helai, umur berbunga rata-rata 45.5 hari, diameter tongkol rata-rata $4.30 \mathrm{~cm}$, panjang tongkol rata-rata $15.35 \mathrm{~cm}$, berat per tanaman rata-rata $214.17 \mathrm{~g}$ dan hasil per petak panen rata-rata $3.38 \mathrm{~kg}$.

\section{DAFTAR PUSTAKA}

Azhari. 2009. Pengaruh Pemberian Konsentrasi Pupuk POC NASA terhadap Pertumbuhan dan

Hasil Tanaman Tomat (Lycopersicum esculentum Mill). Fakultas

Pertanian Universitas Muara Bungo. Jambi.

Badan Pusat Statistik. 2009. Potensi Ekonomi Andalan Provinsi Sumatera Selatan, Palembang.
Diakses di http://www.bps.co.id, tanggal 03 Februari 2011.

Darmanti 2006. Produksi Tanaman Jagung Manis (Zea mays L. saccharrata) yang diperlakukan dengan Kompos Kascing dengan Dosis Berbeda.

Derna, H. 2007. Jagung Manis. Diakses dihttp://www.scribd . com /do/3815872 /jagung manis-no4. pdf, tanggal 18 September 2011.

Hanolo, W. 1997. Tanggapan Tanaman Selada dan Sawi terhadap Dosis dan Cara Pemberian Pupuk Cair Stimulan. Jurnal Agrotropika.

Harizamry. 2007 .JagungManis .Artikel .Diakses dihttp ://harizamrry.com /2007// ../ Tanaman-Jagung-ManisSweet-Corn, tanggal 7 Mei 2011.

Lingga dan Marsono. 2004. Petunjuk Penggunaan Pupuk. Penebar Swadaya. Bogor.

Nihayati, E. dan Damhuri. 2004. Pengaruh Porasi dan Waktu Pemberian Urea terhadap Pertumbuhan dan Produksi Jagung Manis Varietas SO-2. Diakses di http//digilib,brawijaya,ac.id. tanggal 2 Juni 2011.

Parman. 2007. Pengaruh Pemberian Pupuk Organik Cair terhadap Pertumbuhan dan Produksi Kentang. Laboratorium Biologi Struktur dan Fungsi Tumbuhan Jurusan Biologi FMIPA, Universitas Diponogoro. Semarang.

Rahmi dan Jumiati. 2007 . Tanaman Jagung Manis (Sweet Corn). Diakses di

www.usahawantani.com/.../Tanama n-Jagung-Manis-Sweet.Corn. tanggal 4 April 2011. Pengaruh Konsentrasi dan Waktu Pemumpukan POC Super ACI terhadap Pertumbuhan dan Hasil Jagung Manis. Fakultas Pertanian Universitas Tujuh Belas Agustus 1945, Samarinda. 
Rizqiani, N.F.,E. Ambarwati, N.W. Yuwono. Pengaruh Dosis dan Frekuensi Pemberian Pupuk Organik Cair terhadap Pertumbuhan dan Hasil Buncis (Phaseolus vulgaris L.) Dataran Rendah. Jurnal Ilmu Tanah dan Lingkungan.

Sudarsana, N. K. 2000. Pengaruh Efektifitas Microorganisme-4 (EM4) dan Kompos terhadap Produksi Jagung Manis (Zea mays saccharata Sturt) pada Tanah Entisol. Diakses dihttp ://www.unmul.ac.id/dat/pub/frontir/ sudarsana/pdf, tanggal 7 Mei 2011.

Sutedjo, M. M, 2008. Pupuk dan Cara Pemupukan. Rineka Cipta. Jakarta.
Simanungkalit, R, D, M. dan Suriadikarta, D, A. Pupuk Organik dan Pupuk Hayati. Diakses di http://balittanah.deptan.go.id/doku mentasi/.../pupuk\%2 organik.pdf. tanggal 23 Juni 2011.

Tim Karya Tani Mandiri. 2010. Pedoman Bertanam Jagung.

Yulianti, D. 2010. Pengaruh Hormon Organik dan Pupuk Organik Cair (POC) Super Nasa terhadap Produksi Tanaman Jagung Manis (Zea mays saccharataSturt). Diakses dihttp ://penelitian organik penelitian . blogspot . com/2010, tanggal 8 Mei 2011. 